\title{
CYP21A2 wt Allele
}

National Cancer Institute

\section{Source}

National Cancer Institute. CYP21A2 wt Allele. NCI Thesaurus. Code C52351.

Human CYP21A2 wild-type allele is located in the vicinity of $6 \mathrm{p} 21.3$ and is approximately 3 $\mathrm{kb}$ in length. This allele, which encodes cytochrome P450 21 protein, plays a role in the 21-hydroxylation of steroids. Gene conversion events involving the CYP21A2 gene and a nearby pseudogene putatively account for many cases of steroid 21-hydroxylase deficiency. CYP21A2 gene dysfunction causes congenital adrenal hyperplasia. 